\title{
A STUDY OF ORGANIZATIONAL CITIZENSHIP BEHAVIOUR OF TEACHERS AT SECONDARY SCHOOL LEVEL
}

\author{
Farhat Parveen \\ Ph.D. Research Scholar, \\ Department of Education, NUML, \\ Islamabad, Pakistan \\ Email: farhat_awan@live.com

\section{Shazia Zamir} \\ Assistant Professor, \\ Department of Education, NUML, \\ Islamabad, Pakistan \\ Email: szamir@numl.edu.pk
}

\author{
Aisha Bibi \\ Lecturer, \\ Assistant Professor, \\ Department of Education, NUML, \\ Islamabad, Pakistan \\ Email: aishabibi@numl.edu.pk
}

\begin{abstract}
The existing research study was aimed to study the organizational citizenship behaviour of teachers at Secondary level. The nature of this research study was descriptive and gathered the data by survey method. Hundred male and hundred female teachers teaching at Secondary level were chosen by stratified sampling technique from the Islamabad Model Secondary Schools. A standardized questionnaire based on Organizational Citizenship Behavior Scale (OCBS) of 24 items developed by Podsakoff and Moorman (1995) was employed to gather data which have five subscales. Mean, Standard deviation, an independent sample t-test and ANOVA were applied for data analysis. The consciousness dimension has shown high mean score value as compare to the other dimensions of OCB. An independent t-test was employed to see the major difference regarding OCB of male and female teachers. Results indicated that there is a substantial difference in OCB between male and female teachers, moreover results also displays that male teachers have considerably higher level of OCB than female teachers. There is no significant difference found in OCB of teachers based on their marital status and age group. Educational administration should work out on fostering a perception of OCB in their institutions to improve their
\end{abstract}


teaching standard and teachers should also be given incentives by their heads in order to exhibit high level of OCB that will be resulted in their improved performance.

\section{KEYWORDS}

Organizational citizenship behaviour, altruism, civic virtue, conscientiousness, courtesy, sportsmanship, analysis

\section{INTRODUCTION}

Organizational Citizenship Behavior (OCB), a significant attribute of educational employees, is stated as a set of work centered behavioral forms that go beyond the prime job requirement of the workers (Begum, 2005). Podsakoff et al., (2009) defined organizational citizenship behaviour as workers' extra-role actions, usually demonstrating discrete conduct and behavior that is unrestricted, not exactly or unambiguously acknowledged by the prescribed incentive procedure, and in the cumulative manner encourages the effectual and valuable working of the organization. Instances of this behaviour in educationalists comprise recognizing the achievement of their fellows, talk about an educational trouble to a co-worker who is proficient in that discipline, facilitating the research scholars of other teachers, and functioning for the respectability of the organization instead of acquiring individual recognition. OCB logically signifies those conducts and behaviours that have an influence on the institution as well as on the workers (Poncheri, 2006). Therefore, we can express that OCB is a kind of intended conduct that can influence an institution in a progressive manner.

last few years have observed a remarkable growth in the examination of organizational citizenship behavior (OCB), afterward exploration has regularly revealed its relations with a congregation of progressive administrative results, containing numerous characteristics of structural efficiency (OCB commonly denotes (Organ, 2000, p. 4). The very spirit of the supporters' creating very valuable strategies for their associations and organizations since last few years. intended and discretionary actions are asserted to have occurred in the functioning cluster and therefore further investigation have been completed more commonly connected to extra-role conducts of the fellows. In this context, extra-role conducts have turned out to be very significant for administrations and organizations. These actions and behaviours may possibly be described as intended actions apart from prescribed administrative necessities. In addition, extra-role conducts can be stated as organizational citizenship behaviours. Organizational citizenship behaviours are in an communication by means of administrative and organizational formation.

Organizational citizenship behaviours (OCBs) are unrestricted worker conducts and 
behaviours, like facilitating co-worker staffs or willingly upholding the organizational standards, which are considered vital providers to numerous features of execution in administrations. The most significant feature of OCBs is that the described actions and behaviours are accessible without obstruction by workers; they are involved in of their own accord. On the other hand, for certain personnel, these types of conducts and behaviours may possibly be reflected expected or necessitated as role of the workers in- job instructions.

Organizational citizenship behavior (OCB) denotes to the actions of persons that promote effectiveness in organizational functioning. OCB achieves this efficiency and effectiveness by offering an optimistic societal and emotional atmosphere in which assigned job can be successful. OCB is imperative to workers for the reason that it develops communal associations that effect work performance of employees. OCB is one of the supreme considered subject matter in organizational behavior, with various printed theoretic works, major exploration, descriptive analyses, revised volumes, and meta-analyses that refer to the description and working of the OCB.

The fundamentals of OCB are embedded in Barnard 1938 and the concept that persons' readiness to work together is remarkably significant and crucial to the effectiveness of an organization. In the same way, Katz 1964 indicates to OCB with its statement that, in addition to enrolling and remaining with the association and sustaining output and performance criterions, workers need to naturally go afar from their assigned roles. Katz and Kahn (2005) lengthens this notion by explaining impulsive actions that are fundamentally accommodating and completely essential to administrative working. Bateman and Organ (2003) investigated this concept and discovers that gratification is an significant forecaster of citizenship behavior. The expression OCB, on the other hand, was invented in 1983 by Smith, et al. These intellectuals were captivated by the query of why OCB is vital for the efficiency of organizations. Subsequent from this, these researchers have also searched to classify actions and behaviours that are significant to administrations.

Jenaabadi (2013) indicated in his study that the OCB in female teachers is higher as compared to male teachers. Organ \& Rayan (1995) also believed that gender is considered one of the predictable of OCB in addition to it is anticipated that female teachers as compared to male teachers have been surpassed in sacrifice and courteousness elements. Kidder (2002) advocated the superiority of female teachers regarding OCB. Kidder \& Mc Lean Park (2001) expressed their views that OCB of female is higher in female dominated jobs like teaching. On the other hand, Ahmet (2016) found out in his study that male teachers' insights on the organizational citizenship behaviors is higher as compared to female ones. The point that male teachers have superior average of perceptions can be inferred in the manner that they 
have a more positive viewpoint to appraise the organizational citizenship behaviors in the institutions where they do job. Due to contrasting findings of researchers with reference to male and female teachers $\mathrm{OCB}$, the study was aimed to identify genderbased difference regarding OCB at Secondary level.

\section{LITERATURE REVIEW}

Organizational citizenship behavior (OCB) is well-thought-out fundamental for organizations' execution and overall performance, and there is also a noteworthy attentiveness in features that promote it. Though, latest investigative studies have probed about the entire positivity of OCB as well as directed to its understudied probable adversative influences (e.g., on workers' welfare). Latest descriptions of OCB are comprehensive, and may possibly consist of all functioning that helps the societal and emotional situation of the organization/workers (Organ, 2001). Still, a universal subject in the majority explanations is that in their core, OCBs are conducts and behaviors that go further than the workers' certified work explanation as well as comprise actions such as facilitating others, containing added duties, and upholding inventiveness (Organ et al., 2006; Bolino et al., 2013)

Organizational Citizenship Behavior (OCB), however difficult to enforce by the institute or association, stimulates the efficient working of the institution by means of an unrestricted discrete conduct and behavior of workers and play a role to the organizational development in numerous means. Persons that exhibit OCB remain eager to work together and magnify their assurance afar from the fixed responsibilities as well as recompenses provided by way of the organization having the purpose of attaining additional momentous objectives. Therefore, any institution and organization be able to target to upsurge OCB of its workers. Still, to be capable to do that, it need be acquainted with the extents of OCB that are affected also.

Organizational Citizenship Behavior (OCB) indicates that worker's conduct and behavior is well-matched together with an administration's objectives plus procedures. Though the notion has progressed with the passage of time in addition its description has been diverse, its core, past history, as well as scopes have continued comparatively unaffected. One of the most basic indications of Organizational Citizenship Behavior is the study of Barnard (1930) and Katz \& Kahn (2005) who supposed that additional positioned conduct and behavior of workers is the exhibition of their self-sacrificing as well as intended conducts and behaviors in the direction of the attainment of organizational purposes and objectives (Katz \& Kahn, 2005). Up till now, the expression "OCB" was initially devised by Bateman (2003) who well-described it as a flexible discrete action that stimulates the successful execution of an institution, though that is not obviously acknowledged by means of the prescribed incentive procedure (Organ, 2005). 
OCB is grounded on the approaches of a person concerning work necessities also displays person's wish as well as interest to exceed the institute's outlooks in an attempt to boost the productivity of the institute beyond the defined responsibilities ( Sales, 2000). According to Organ (2001), OCB is displayed by workers who are exceedingly dedicated towards an institute in addition those who are the example of the "virtuous fighter condition." Optimistic OCB is, therefore, categorized by personnel connecting in additional-role actions that are not certainly specified in their work portrayals, however that are in good will of administrative organization wellbeing as well as make available the person's related to central inspiration.

Organizational Citizenship Behavior has been a focus of various research papers that has led to diverse kinds of OCB connected to distinct as well as administrative based consequences (Podsakoff, Whiting, \& Blume, 2009 ). The supreme substantial past history of OCB on the specific point are work gratification as well as work embeddedness, worker commitment, administrative assurance, also self-efficacy, whereas backgrounds of OCB associated to the structural and administrative stage are social source actions, decreased expenditures, improved efficiency as well as competence, transformational management, philosophy, consumer gratification, etc. Respectively of these precursor's upsurges $\mathrm{OCB}$, that absolutely marks backgrounds in return and has an added constructive influence on OCB.

The greatly workers are contented by their careers, they get involved further and rooted to their institute and as a result more eager to perform further than prescribed prospects (Cho \& Ryu, 2009) . In the same way, the high-ranking administrative assurance, particularly emotional liability is absolutely associated to OCB elements selflessness as well as obedience (Zheng, 2012 ). Correspondingly, persons with the advanced opinion of their competences are more possible to be taking the initiative in addition to take part in accomplishments that go afar their prescribed work description, for instance to involve in intended function (Brown, 2012).

According to Organ (2001), self-sacrifice plus universal acquiescence are two foremost aspects of OCB, whereas Organ recognized five elements of OCB i-e altruism, conscientiousness, civic virtue, courtesy, as well as sportsmanship that afterwards (Organ,2005) extended by harmony retaining and liveliness directing. In describing OCB, literary works in the previous years have recognized two foremost methodologies as function goes yonder the indicated character necessities as well as not acknowledged by the prescribed incentive structure. As accurately stated by Castro (2004) it is not comfortable to discriminate concerning "function" and "additional function" executions as administrative plus worker insights of their assistants' functioning do not relate as well as focus to the gratification of the assistants in the place of work. Numerous research studies indicate to the point that there are five major 
behavior elements which influence for the most part of the modification in behavior and personality in addition to these factors are recognized as Big Five factors that are categorized as conscientiousness, altruism, courtesy, sportsmanship, as well as civic virtue.

Corresponding to Organ's (2001) description, it signifies specific conduct that is flexible, not exactly or obviously acknowledged by means of the prescribed incentive procedure, and in the collective stimulates the effectual as well as efficient working of the institution. Organ (2001) recognized five elements of OCB. These five factors comprise such kind of administrative conducts for example facilitating co-workers, obeying organization procedures, not criticizing, as well as dynamically partaking in administrative matters.

Altruism in easy terms way assisting or effectiveness (Organ, 2001) Altruism signifies aiding other fellows of the association in their responsibilities and tasks. For example, readily assisting new employees, assisting co-fellows who are over-burdened, helping workforces who were inattentive, managing employees to accomplish challenging jobs. Smith, Organ, and Near (2002) described altruism as intended conducts where a worker make available support to a specific person with a specific challenge to accomplish his assigned duty in extraordinary conditions. Altruism denotes to a fellow assisting other fellows of the association in their job. Podsakoff et al. (2000) has expounded that altruism was meaningfully associated to accomplishment assessments also constructive affectivity respectively,

Conscientiousness is an unrestricted conduct that drives fine outside the least possible character necessity degree of the association for instance comply with guidelines and procedures of the particular organization, not demanding additional disruptions, functioning additional-long time (MacKenzie et al, 2003). Conscientiousness is a pattern of functioning fine outside nominally mandatory stages of existence, regularity, and maintenance of house responsibilities, fondness in the direction of safeguarding assets, as well as generally providing an impact of being a trustworthy worker of the institution. If the worker is extremely diligent it indicates that he is exceedingly reliable and wants not as much of direction as well as administration (Podsakoff and MacKenzie, 2002). Altruism and conscientiousness are the two chief or central elements of OCB (Borman et al., 2007). Conscientiousness is employed to specify that a specific person is systematized, well-managed, responsible as well as diligent. Organ (2002) well-defined it as commitment to the work which go beyond prescribed necessities like functioning for long periods, and offer voluntarily to execute responsibilities in addition to obligations. It is exciting to notice that Kidder (2005) hypothesized the statistics that male educators are more expected to involve in careful 
actions than females in observation of the point that males have inclination for impartiality over equal opportunity.

Sportsmanship is described as a readiness to endure the unavoidable troublesomeness in addition to burden of work load with no protesting. (Organ, 2002). It denotes to individual's wish not to criticize while undergoing the unescapable troublesomeness and mistreatment caused in working out a skilled action. Sportsmanship denotes to escape criticizing unreasonably on the subject of the complications confronted in the place of work, being constructive as well as easy-going in the direction of difficulties come into contact with in the place of work. Sportsmanship is display of readiness to put up with insignificant and short-term workforce troublesomeness plus burdens of workload with no complaints, protests, requests, allegations, or objection. This supports to safeguard structural dynamisms for achievement of assignment and to a large degree eases administrators of excessive burden/strain (Organ and Ryan, 2004). Organ (2002) well-defined sportsmanship as the conduct of affectionately enduring the annoyances that are an inevitable function of almost every single administrative situation. Podsakoff and MacKenzie (2001) revealed that virtuous sportsmanship would enrich the self-esteem of the workers at the place of work and as a result decrease worker turnover.

Courtesy denotes to the signs that benefit others to avoid social complications from happening, for instance delivering earlier announcement of the task plan to somebody who is in necessity, referring others beforehand undertaking any proceedings that would disturb them (Organ, 2002). Courtesy or signs are displayed in the apprehension of escaping developments of troubles for related employees (Organ, 2002). For instance, to leave the photo copier or laser printer in upright form for other fellow's usage is an illustration of courteousness at place of work (Organ \&MacKenzie, 2006). A well-mannered worker averts administrators from falling into the model of disaster administration by creating a genuine struggle to escape generating complications for fellow workers (Podsakoff \& MacKenzie, 2004). Courtesy comprises conducts, which emphasis on the avoidance of complications also adopting the essential as well as welltimed actions in order to decrease the consequences of the dilemma in the upcoming days. In easy terms, courtesy indicates the reinforcement communicated by a fellow to other fellow/s of the institute at the time when they are discouraged and comprehend depressed about their specialized progress. Again to recap, research study has presented that workers who display courteousness would decrease dispute with in the group and in this manner lessening the period consumed on clash managing events (Podsakoff et al., 2004). The core notion of courteousness is evading activities that unreasonably create co-workers' perform vigorous. It also consists of providing them adequate communication to become ready as soon as there is an accumulation to their current job burden. 
Civic virtue denotes to the productive contribution in the party-politics procedure of the institute as well as involvement to this procedure by generously as well as openly articulating sentiments, joining get-togethers, conversing with co-workers the matters regarding the institute, and understanding administrative interactions such as correspondences for the welfare of the institute. Civic virtue is conduct on the side of a specific person that specifies that workers devotedly take part in, is energetically engaged in, as well as is apprehensive regarding the lifespan of the institution (Podsakoff et al, 2003). Civic virtue signifies a world-wide attentiveness in, or promise to, to the institute. It displays readiness to partake enthusiastically in administration's proceedings, observe administration's setting for terrorizations as well as prospects, to drive out the finest substitute for the institute. These conducts and behaviours take place at the time when workers regard themselves with the institute and regard themselves to be vital part and parcel of the institute. (Podsakoff et al, 2003). Civic virtue is described as subsidiary partaking in institute party-politics life time also strengthening the organizational purpose of the institute (Deluga, 2006). Civic virtue belongs to the answerability of the workers to energetically as well as gladly take part in the activities of the organization for instance joining consultations and meetings which are not mandatory by the organization in addition to keeping reviewed with the variations in the institute (Organ, 2002). This element of OCB is in fact resultant from Graham's conclusions which indicated that workers must have the obligation to be a virtuous native of the institute (Graham, 2007). These conducts signify workers' acknowledgement of being part of institute in addition to admit the duties which involve as a consequence of being worker of the institute (Podsakoff et al., 2003). Other scholars and investigators have discovered that civic virtue develops the extent of execution and benefit to decrease client grievances (Walz, 2008).

Research study conducted by Tehseen (2016) indicated that the teacher's educators exhibited more involvement for conscientiousness. This display that teacher's educators were more involved towards the benefit of their institution. Result findings of study by Habeeb (2019) indicated results as public and private organization members demonstrated reasonably high scores of conscientiousness as compared to other dimensions of OCB. The results findings described by Jang (2015) discovered that male educators have great level of OCB as contrasted to female educators. Results of the study exhibited that demographic variables like gender, marital status, age do not have any significant difference on OCB. As discovered by Narang and Dwivedi (2010) in their study, that female teachers are more responsible and show greater concern towards student than male teachers. On the other hand, studies by (Rezaian, 2006; Mahnaz et al., 2013; Wanxian and Weiwu, 2007) stated that male teachers exhibit more OCB as compared to female teachers. Findings of the study conducted by Abdullah \& Akhter (2016) also reported similar results. The results of their study showed that male teachers showed more sportsmanship than the female teachers. Study 
conducted by Shahzad (2011) directed findings as demographic variables like age, work experience does relate to citizenship behaviours of university teachers in both Pakistan and England.

\section{RESEARCH OBJECTIVES}

1. To assess level of organizational citizenship behavior of teachers at Secondary School level.

2. To find out the demographic differences i-e gender, marital status, age, regarding organizational citizenship behavior of teachers at Secondary School level.

\section{RESEARCH HYPOTHESIS}

1. There is no significant difference regarding the demographic variables i-e gender, marital status and age with reference to organizational citizenship behavior of teachers at Secondary School level.

\section{RESEARCH METHODOLOGY}

The focused population of the investigative study was 3200 teachers (male and female) teaching at Secondary level in Islamabad Model Secondary Schools. The research study was delimited to the Islamabad Model Schools located in Urban areas of Islamabad and the science teachers currently teaching to class $10^{\text {th }}$. This research study employed simple random sample procedure as the method of choosing samples. The sample size of 200 teachers (100 male and 100 female) were nominated by using stratified sampling technique. Each of the institution were contacted all through a higher level administration who circulated the questionnaire to her or his teachers.

Overall 230 research questionnaires were circulated amongst the various institutions of Islamabad selected through random sampling technique and 210 completely filled questionnaires were given back to researcher. Amongst the ones returned back, 10 were noticed redundant and were rejected. The concluding absolute sample size of the study was 200. The contestants in the research study were teachers teaching at Secondary level in Islamabad Model Secondary Schools. In aggregate, there were 100 male teachers and 100 female respondent teachers working in IMS.

\section{Research Instrument}

Organizational Citizenship Behavior Scale (OCBS) of 24 items developed by Podsakoff and Moorman (1995) has been used by the researcher for this study. The research questionnaire has been closed-ended in order to permit for efficacy as well as efficiency in assembling answers from the targeted sample population and offer comfort of judgement amongst responses (Reja, 2003). It has been make use of a Likert-type scale that demands that the respondent population specify the level of conformity or difference with the items assessing the dimensions of OCB. Respectively 
each item had five answer groups: (1) strongly disagree (2) disagree (3) neutral (4) agree (5) strongly agree.

The research questionnaire comprised the demographic variables and five dimensions of OCB. The demographic variables in the research study were gender, marital status as well as age. Organizational Citizenship Behavior was calculated with a 24-item scale, comprising five elements - conscientiousness (five items), sportsmanship (five items), civic virtue (four items), courtesy (four items), and altruism (six items) (Podsakoff et al., 2009).

Conscientiousness was well-described as a derive of performing in a well manner outside slightly obligatory position as well as job necessities. Sportsmanship was described as a readiness of workers to put up with predictable inopportuneness in addition to attainment of work with no criticizing. Civic virtue was specified as intended contribution in and encouragement of administrative tasks of mutually a proficient as well as societal kind, whereas courtesy was well-defined as the flexible representation of considerate plus understanding conduct and behavior that avoid jobrelated complications for other fellow workers. Altruism was described as intentional activities that benefit a related fellow worker in job-related difficulties.

Major data for the research study was gathered by using research questionnaire. The questionnaire was circulated physically by the investigator to the respondents of this study. All contributors of the study have required to be agreeable to take part in the research study and to fill the whole questionnaire. The questionnaire was circulated in their totality and were gathered afterwards, as per the suitability of the teachers of the study and to eradicate any concerns from the administration of the institution owing to the interruption of teachers from performing out their job responsibilities. Data examination was executed employing IBM SPSS 25.0 statistics package.

\section{RESULTS}

Table 1: Dimensions and the Respective Items in the $O C B Q$

\begin{tabular}{lll}
\hline S.No & Dimensions & Items \\
\hline 1. & Conscientiousness & $1,2,3,4,5,6$ \\
2. & Sportsmanship & $7,8,9,10$ \\
3. & Civic Virtue & $11,12,13,14$ \\
4. & Courtesy & $15,16,17,18,19$ \\
5. & Altruism & $20,21,22,23,24$ \\
\hline
\end{tabular}

This table 1 shows number of items contained by OCB questionnaire 
PJER, Vol 4, Issue 2 (2021)

A study of organizational...

\begin{tabular}{|c|c|c|}
\hline \multicolumn{3}{|c|}{ Mean Score of teachers regarding OCB dimensions } \\
\hline Dimensions & Mean & Remarks \\
\hline OCB Total & 4.14 & Agree \\
\hline Conscientiousness & 4.21 & Agree \\
\hline Courtesy & 4.19 & Agree \\
\hline Altruism & 4.09 & Agree \\
\hline Sportsmanship & 4.08 & Agree \\
\hline Civic Virtue & 4.01 & Agree \\
\hline
\end{tabular}

showed the mean scores of five dimensions of OCB. According to this table, the mean score of Conscientiousness (4.21) was found highest and the mean score of Civic Virtue (4.01) was found lowest among the other dimensions of OCB. Moreover, the teachers displayed agreement regarding all five dimensions of OCB. The teachers showed more involvement towards Conscientiousness that is institution centred dimension of OCB. It displays that teachers are more focused in the direction of providing benefit to their institution.

Table 3: Gender Wise Mean, Standard Deviation and t-test based on Secondary School teacher's OCB.

\begin{tabular}{lcccccc}
\hline OCB Dimensions & \multicolumn{2}{c}{ Males $(\mathbf{N}=\mathbf{1 0 0})$} & \multicolumn{2}{c}{ Females $(\mathbf{N = 1 0 0})$} & $\mathbf{t}$ & $\boldsymbol{P}$ \\
\hline & $\mathrm{M}$ & $\mathrm{SD}$ & $\mathrm{M}$ & $\mathrm{SD}$ & & \\
OCB Total & 4.350 & .560 & 3.91 & .810 & .000 & .000 \\
Conscientiousness & 4.37 & .622 & 4.03 & .974 & .003 & .000 \\
Sportsmanship & 4.39 & .670 & 3.78 & .819 & .000 & .001 \\
Civic virtue & 4.30 & .609 & 3.76 & .729 & .000 & .033 \\
Courtesy & 4.41 & .635 & 3.97 & .954 & .000 & .000 \\
Altruism & 4.17 & .594 & 3.98 & .968 & .089 & .000 \\
\hline
\end{tabular}

According to the results indicated in Table 3, gender differences for OCB were found significant. It means that there existed significant gender differences in OCB between male and female teachers teaching at Secondary level. Therefore, the hypothesis 'There is no significant gender- based differences regarding OCB of Secondary School teachers' was rejected. However, results indicated that male teachers have shown higher level of OCB (4.35) as compared to female teachers (3.91). Gender has a substantial effect on all dimensions of OCB. This confirmed that both male and female Secondary School teachers have not similar level of OCB.

Table 4: $\quad$ Marital status Wise Mean, Standard Deviation and t-distribution based on Secondary School teacher's OCB. 


\begin{tabular}{|c|c|c|c|c|c|c|}
\hline \multirow[t]{2}{*}{ OCB Dimensions } & \multicolumn{2}{|c|}{ Married $(\mathrm{N}=148)$} & \multicolumn{2}{|c|}{ Unmarried (N=52) } & \multirow[t]{2}{*}{$\mathbf{t}$} & \multirow[t]{2}{*}{$p$} \\
\hline & $\mathrm{M}$ & SD & $\mathrm{M}$ & SD & & \\
\hline OCB Total & 4.17 & .700 & 4.02 & .795 & .200 & .095 \\
\hline Conscientiousness & 4.26 & .750 & 4.05 & 1.02 & .132 & .006 \\
\hline Sportsmanship & 4.12 & .772 & 3.99 & .902 & .327 & .038 \\
\hline Civic virtue & 4.03 & .719 & 4.03 & .736 & .945 & .636 \\
\hline Courtesy & 4.25 & .792 & 4.01 & .940 & .066 & .084 \\
\hline Altruism & 4.11 & .837 & 3.98 & .712 & .318 & .812 \\
\hline
\end{tabular}

According to the results indicated in Table 4, marital status wise differences for OCB were found non- significant. It means that there existed non-significant marital status wise differences in OCB between teachers teaching at Secondary level except the Conscientiousness and Sportsmanship. Therefore, the hypothesis 'There is no significant difference regarding OCB of Secondary School teachers based on their marital status' was failed to reject. However, results indicated that married teachers have shown higher level of OCB (4.17) in all dimensions of OCB as compared to female teachers (4.02). However, both male and female teachers have showed same level of mean score in the Civic Virtue.

Table 5: $\quad$ Mean, Standard Deviation and One Way ANOVA based on OCB of teachers with respect to their age.

\begin{tabular}{|c|c|c|c|c|c|c|}
\hline & & $\begin{array}{l}\text { Sum of } \\
\text { Squares }\end{array}$ & df & $\begin{array}{l}\text { Mean } \\
\text { Square }\end{array}$ & $\mathbf{F}$ & sig \\
\hline \multirow[t]{3}{*}{ Conscientiousness } & $\begin{array}{l}\text { Between } \\
\text { groups }\end{array}$ & .561 & 3 & .187 & .266 & .850 \\
\hline & $\begin{array}{l}\text { Within } \\
\text { groups }\end{array}$ & 137.523 & 196 & .702 & & \\
\hline & Total & 138.083 & 199 & & & \\
\hline \multirow[t]{3}{*}{ Sportsmanship } & $\begin{array}{l}\text { Between } \\
\text { groups }\end{array}$ & .625 & 3 & .208 & .316 & .814 \\
\hline & $\begin{array}{l}\text { Within } \\
\text { groups }\end{array}$ & 129.181 & 196 & .659 & & \\
\hline & Total & 129.806 & 199 & & & \\
\hline \multirow[t]{3}{*}{ Civic Virtue } & $\begin{array}{l}\text { Between } \\
\text { groups }\end{array}$ & .327 & 3 & .109 & .206 & .892 \\
\hline & $\begin{array}{l}\text { Within } \\
\text { groups }\end{array}$ & 103.462 & 196 & .528 & & \\
\hline & Total & 103.789 & 199 & & & \\
\hline Courtesy & $\begin{array}{l}\text { Between } \\
\text { groups }\end{array}$ & .459 & 3 & .153 & .215 & .886 \\
\hline
\end{tabular}




\begin{tabular}{rlrrrrr}
\hline & Within & 139.336 & 196 & .711 & & \\
groups & 139.795 & 199 & & & \\
Totral & & & & & \\
& Between & 2.436 & 3 & .812 & 1.250 & .293 \\
& $\begin{array}{l}\text { groups } \\
\text { Within }\end{array}$ & 127.332 & 196 & .650 & & \\
groups & 129.768 & 199 & & & \\
& Total & & & & \\
\end{tabular}

According to table 5, One Way ANOVA is explained related to dimensions of OCB i-e Conscientiousness, Sportsmanship, Civic Virtue, Courtesy and Altruism. It indicates a non-significant difference $[\mathrm{F}=.266 . \mathrm{p}=.850, \mathrm{~F}=.316 . \mathrm{p}=.814, \mathrm{~F}=$. 206. $\mathrm{p}=.892, \mathrm{~F}=.215 . \mathrm{p}=.886, \mathrm{~F}=1.25 . \mathrm{p}=.293$ ] of Secondary School teachers OCB related to age group at .05 level of significance. According to this result, hypothesis 'There is no significant difference regarding OCB of Secondary School teachers based on their age group' is failed to reject.

\section{DISCUSSION}

This research study signifies an attempt to analyse the organizational citizenship behaviour of teachers at Secondary level. Findings of the study will support the highest administration of educational institutions to set up suitable atmosphere to heighten the level of Organizational Citizenship Behavior in academic staff at secondary level.

As statistical findings showed in the former section, Table 2 shows the mean scores of five dimensions of OCB. According to this table, the mean score of Conscientiousness was found highest and the mean score of Civic Virtue was found lowest among the other dimensions of OCB. Moreover, most of the teachers agreed on Conscientiousness, Courtesy and Altruism. Teachers showed neutral response towards Sportsmanship and Civic Virtue. Research study conducted by Tehseen (2016) also indicated similar results as according to her study, the teacher's educators exhibited more involvement for conscientiousness. This display that teacher's educators were more involved towards the benefit of their institution. Result findings of study by Habeeb (2019) indicated similar results as public and private organization members exhibited reasonably high scores of conscientiousness as compared to other dimensions of OCB. Educational administration should work out on fostering a perception of OCB in their institutions to improve teaching standard. According to the results indicated in Table 3, gender differences for OCB were found significant. It means that there existed significant gender differences in OCB between male and female teachers teaching at Secondary level. Therefore, the hypothesis 'There is no significant gender- based differences regarding OCB of Secondary School teachers' was rejected. However, results indicated that male educators have demonstrated 
greater level of OCB as compared to female teachers. This confirmed that both male and female Secondary School teachers have not similar level of OCB. As discovered by Narang and Dwivedi (2010) in their study, that female teachers are more responsible and show greater concern towards student than male teachers. On the other hand, studies by (Rezaian, 2006; Mahnaz et al., 2013; Wanxian and Weiwu, 2007) stated that male teachers exhibit more OCB as compared to female teachers. Findings of the study conducted by Abdullah \& Akhter (2016) also reported similar results. The results of their study showed that male teachers showed more sportsmanship than the female teachers

According to the results indicated in Table 4, marital status wise differences for OCB were found non- significant. It means that there existed non-significant marital status wise differences in OCB between teachers teaching at Secondary level. Therefore, the hypothesis 'There is no significant difference regarding OCB of Secondary School teachers based on their marital status' was failed to reject. However, results indicated that married teachers have shown higher level of OCB as compared to female teachers. Findings of study by Imran (2017) also support that marital status of teachers does not affect their OCB. Research study of Akhter (2016) depicted contrasting results as regarding civic virtue, there was a significant influence as married teachers reported more civic virtue than single teachers. According to table 5, One Way ANOVA is explained related to dimensions of OCB i-e Conscientiousness, Sportsmanship, Civic Virtue, Courtesy and Altruism. It indicates a non-significant difference of Secondary School teachers OCB related to age group at .05 level of significance. According to this result, hypothesis 'There is no significant difference regarding OCB of Secondary School teachers based on their age group' is failed to reject. Study conducted by Shahzad (2011) indicated opposite findings as demographic variables like age, work experience does relate to citizenship behaviour of teachers in both Pakistan and England. Nisar (2017) stated in his study that teachers who are in age of 46 or above are more committed to OCB than the young teachers.

\section{CONCLUSION}

The Conscientiousness was found highest and the Civic Virtue was found lowest among the other dimensions of OCB. However, the teachers displayed agreement regarding all five dimensions of OCB.

There is a substantial difference in OCB between male and female educators, moreover findings also display that male teachers have significantly higher level of OCB than female teachers. There is no significant difference in OCB based on marital status and age of teachers. 


\section{RECOMMENDATIONS}

1. Educational institution management should organize seminars / conferences / workshops to uphold the vision of the school and to cultivate sense of civic virtue among teachers to inspire them to elevate the standard of their school and to increase team work relationship in institution. Teachers should also boost up by the school administration in expressing their thoughts, attend meetings, talk over the concerns of the day with fellow teachers, and reading organizational exchange of ideas such as mails to develop their school's image.

2. Educational administration should work out on fostering a perception of OCB in their institutions to improve their teaching standard and teachers should also be given incentives by their heads in order to exhibit high level of OCB that will be resulted in their improved performance.

3. The results of this study showed significant difference in organizational citizenship regarding gender difference. Consequently, this demographic variable must to be specified more concern within the training modules of secondary teachers.

4. Educational institution's administration support may be an effectual procedure for boosting teacher OCBs encompassing all dimensions.

5. Future researcher should magnify this category of research study to other educational levels as higher secondary and university level and populations.

6 . The findings of this study make accessible valuable understanding to teachers who by making sure the display of organizational citizenship behavior can rise the standard of their institutes.

\section{REFERENCES}

Abdullah, A; Akhter, S. (2016). Job Satisfaction through Organizational Citizenship Behaviour: A Case of University Teachers in Pakistan. Alberta Journal of Educational Research, Vol. 62.2, Summer 2016, 134-149

Begum, N, 2005. The relationship between social power and organizational citizenship behavior: The meditational role of procedural justice, organizational commitment, and job satisfaction in context of a private commercial bank in Bangladesh, Independent University, Journal of Business Ethics, in press.

Bolino, M. C., Klotz, A. C., Turnley, W. H., and Harvey, J. (2013). Exploring the dark side of organizational citizenship behavior. J. Organ. Behav. 34, 542-559.

Brown, K. M. , Hoye, R. , \& Nicholson, M. (2012). Self-esteem, self-efficacy, and social connectedness as mediators of the relationship between volunteering and well-being. Journal of Social Service Research , 38(4), 468-483.

Castro, C. B., Armario, E. M. \& Ruiz, D. M. (2004). The influence of employee organizational citizenship behaviour on customer loyalty. International Journal of Service Industry Management, 15, 1, 27-53.

Cho, Y. B. , \& Ryu, J. R. (2009). Organizational citizenship behaviors in relation to job embeddedness, organizational identification, job performance, voluntary turnover 
intention in Korea. International Business \& Economics Research Journal, 8(7), 5168.

Deluga, R.J. (2006) "Leader-member exchange quality and effectiveness ratings: The role of subordinate-supervisor conscientiousness similarity", Group and Organization Management, Vol. 23 No. 2, pp. 189-216.

Graham, J. W. (1991). An essay on organizational citizenship behavior. Employee Responsabilities and Rights Journal, 4, 249-270.

Imran, A \& Nisar, A. (2017). Organization citizenship behaviour, psychological empowerment and demographic characteristics: Teachers' perspective. International Journal of Advanced and Applied Sciences

Jenaabad, H .(2013). Organizational Citizenship Behavior, Job Satisfaction and Commitment to School: Is There Any Significant Difference between Male and Female Teachers? World Journal of Education. Published by Sciedu Press 75 ISSN 1925-0746.

Jha, S. (2014). Transformational leadership and psychological empowerment: Determinants of organizational citizenship behavior. South Asian Journal of Global Business Research , 3(1), 18-35.

Katz, D. \& Kahn, R. L. (2005). The social psychology of organizations. New York: John Wiley and Sons

Kidder, L. K. (2002). The influence of gender on the performance of organization citizenship behaviors. Journal of Management, 28, 629-648. http://dx.doi.org/10.1177/014920630202800504

Kidder, D. L., \& Mclean Parks, J. (2001). The good soldier: Who is s(h)e? Journal of Organizational Behavior, 22, 939-959. http://dx.doi.org/10.1002/job.119

Kidder, D. L., \& McLean Parks, J. (2005). The good soldier: Who is (s)he? In D. P. Moore (Ed.), Academy of Management Best Papers Proceedings, 363-367.

Lee, K., \& Allen, N.J. (2002). Organizational citizenship behavior and workplace deviance: the role of affect and cognition. Journal of Applied Psychology, 87, 131- 142

MacKenzie, S. B., Podsakoff, P. M., \& Fetter, R. (1993). The impact of organizational citizenship behaviour on evaluations of sales performance. Journal of Marketing, 57:70-80.

Organ, D. W., \& Ryan, K. (1995). A meta-analytic review of attitudinal and dispositional predictors of organizational citizenship behavior. Personnel Psychology, 48, 775-802. http://dx.doi.org/10.1111/j.1744-6570.1995.tb01781.x

Organ, D. (2005). Organizational citizenship behavior: recent trends and developments. Annual Review of Organizational Psychology and Organizational Behavior , 4(1), 295-306

Organ, D. W. (1988). Organizational citizenship behaviour: The good soldier syndrome. Lexington, MA: Lexington Books.

Organ, D. W. (1990b). The subtle significance of job satisfaction. Clinical Laboratory Management Review, 4:94-98.

Organ, D. W., \& Ryan, K. (1995). A meta-analytic review of attitudinal \& dispositional predictors of organizational citizenship behavior. Personnel Psychology, 48: 775802.

Organ, D. W. (1997). Organizational citizenship behaviour: It's construct clean-up time. Human Performance, 10: 85-98. 
Organ, D. W., Podsakoff, P. M., \& MacKensie, S. B. (2006). Organizational Citizenship Behavior. Its Nature, Antecedents, and Consequences. Sage Publication: Thousands Oaks.

Podsakoff, N.P., Whiting, S.W., Podsakoff, P.M., \& Blume, B.D. (2009). Individualand organizational-level consequences of organizational citizenship behaviors: A metaanalysis. Journal of Applied Psychology, 94, 122-141.

Podsakoff, P. M., MacKenzie, S. B., Moorman, R. H., \& Fetter, K. (1990). Transformational leader behaviours and their effects on followers' trust in leader, satisfaction, and organizational citizenship behaviours. Leadership Quarterly, 1: 107- 142.

Podsakoff, P. M., Ahearne, M., \& MacKenzie, S. B. (1997). Organizational citizenship behaviour and the quantity and quality of work group performance. Journal of Applied Psychology, 82(2): 262-70.

Podsakoff, P. M., MacKenzie, S. B., Paine, J. B., \& Bachrach, D. G. (2000). Organizational citizenship behaviours: A critical review of the theoretical and empirical literature and suggestions for future research. Journal of Management, 26: 513-563.

Poncheri, R. (2006). The impact of work context on the prediction of job performance. North Carolina State University, Raleigh, NC.

Shahzad, K. (2011). Development of a model of Organizational citizenship behaviour: A comparative study of university teachers from a developing and a developed country. Mohammad Ali Jinnah University,Islamabad, Pakistan.

Smith, C. A., Organ, D. W., \& Near, J. P. (2002). Organizational citizenship behaviour: Its nature and antecedents. The Journal of Applied Psychology, 68: 653-663.

Tahseen, N. (2015). Effect of Organizational Justice on faculty trust and Organizational citizenship behaviour in teacher - education faculties.

Walz, S.M., Niehoff, B.P., (2008). Organizational citizenship behaviors and their effects on organizational effectiveness in limited. Academy of Management Best Paper Proceedings, 307-311.

Williams, L., \& Anderson, S. (1991). Job satisfaction and organizational commitment as predictors of Organizational citizenship and in-role behaviors. Journal of Management, 17, 601-617.

Zheng, W. , Zhang, M. , \& Li, H. (2012). Performance appraisal process and organizational citizenship behavior. Journal of Managerial Psychology , 27(7), 732-752. 